\title{
A Design Architecture for Developing Agricultural Product Forecasting System Application for Farmers
}

\author{
Joe Marie D. Dormido, Thelma D. Palaoag
}

\begin{abstract}
One-third of the labor force in the Philippines is engaged in farming. Farmers played an important role in providing every family with the fresh food needed daily for our health. Helping farmers build a stronger network to market their products eventually created sustainability within the agricultural sector. The establishing of agricultural forecasting mobile application shall serve both the farmers and traders better in making sure that the harvested crops earned profits. The developed architecture design shall be adopted for agricultural forecasting applications. The study examined the factors considered in the development of a mobile application assistant to the agricultural sector. The use of different statistical tools helped in providing in-depth analysis which resulted in a more accepted designed for the farmers. The results show, that having identified some common problems in providing online services shall likewise solve certain issues and offer solutions to the best practices in the forecasting of agricultural production. It indicated that having a mobile agricultural forecasting application solved the issues in the waste production of farm products. The application shall help the farmers checked the level of crop demand in the market and navigate the place in which the demand is high in farm production in the participated trading post. This became beneficial to both farmers and the government in strengthening the agricultural sector, which is far behind from other developing countries.
\end{abstract}

Index Terms - agricultural product, agricultural sector, forecasting, mobile application.

\section{INTRODUCTION}

The agricultural sector in the Philippines is an important part of the economy and provides a livelihood for one in three people according to the Organization for Economic Cooperation and Development Director of Agriculture Ken Ash [1]. The demand for farm products, influenced mainly by gradual increases in population and consumer incomes, on the other hand, has increased much more slowly than supply [2]. Through buying locally grown produce, consumers are giving their support to local producers as well as helping to revitalize rural economies [3]. But due to a lack of local government programs to increase and sustain production ends up the farmers lack support, training and a moral boost [5]. The frequent and excessive fluctuation of agricultural and livestock products price is not only harmful to residents' living, but also affects CPI (Consumer Price Index) values, and even leads to social crisis, which influences social stability [4]. Improvements to productivity could be achieved through increased on-farm investment,

Revised Manuscript Received on July 18, 2019.

Joe Marie D. Dormido, College Engineering and Information Technology, Carlos Hilado Memorial State College, Bacolod City, Philippines (email: joe.dormido@chmsc.edu.ph)

Thelma D. Palaoag, College of Information Technology and Computer Science, University of the Cordilleras, Baguio City, Philippines (email: tpalaoag@gmail.com) but this is currently impeded by insecure property rights and restrictions on land-market transactions, according to the report. Policies that enable further consolidation of farm operations could also boost productivity [1].

The farmers' uptake of IT is disappointingly modest, even for applications that have demonstrated economic benefits [6]. This lack of interest in IT by farmers is often explained by factors such as low levels of education and relatively high age [7]. Ascough et al. did, however, find very complex associations between farmers' use of IT and their education, age, and experience; it seems that the main reason for using IT was a lack of agricultural competence, whereas the most experienced farmers did not seem to find significant benefits from the IT applications available to them [8]. This leads to farmer limited access to technology, especially in supporting the effort of the government to help adopt new systems for a sustainable society. But today's advancement and low cost of technology become an ally to people, it is not any more a problem to push a solution that makes the effort of the government agency a reality. Providing smallholder farmers with agricultural information could improve economic development, by helping them to grow more crops, which they could then sell for more money [10]. Farm businesses appear to have much to gain from the use of Internet technology, particularly to anyone interested in the adoption of information and communication technology in micro-business, and/or in the development of e-commerce in the farm sector [11]. The ability to reliably forecast crop production, yield and quality is valuable for economic planning and commodities forecasting as well as ensuring global food security [12]. Forecasts for agricultural production and prices are intended to be useful for farmers, governments, and agribusiness industries. Because of the special position of food production in a nation's security, governments have become both principal suppliers and main users of agricultural forecasts [9]. The study provided the architectural design some important features to promote the project in support of the government program that benefited the farm sector. Thus, developing a mobile application that oversee the required volume of farm goods deliver to the market is important so that there is no waste in agricultural products.

\section{METHODOLOGY}

The researcher started gathering data by coordinating with the provincial government of Negros Occidental and 


\section{A DESIGN ARCHITECTURE FOR DEVELOPING AGRICULTURAL PRODUCT FORECASTING SYSTEM APPLICATION FOR FARMERS}

identified two established trading posts, which are Silay and Victorias. These cities have a list of farmers and associations that is important and reliable to conduct the study. The rationales for the selection were as follows: (a) the visibility of farmer association in the province; (b) the local government unit has a well-established trading post, and (c) the local government has a strong presence in the area.

\section{A. Research Design}

The research was designed to assess, report, and provide data for the development of the agricultural forecasting system shown in figure 2. Descriptive statistics, as the name implies, is the process of categorizing and describing the information and thematic analysis strives to identify patterns of themes in the interview data. [13, 14]. For this study, quantitative data were collected and analyzed through survey questionnaire and descriptive statistics, while qualitative data employed semi-structured in-depth interviews and thematic analysis.

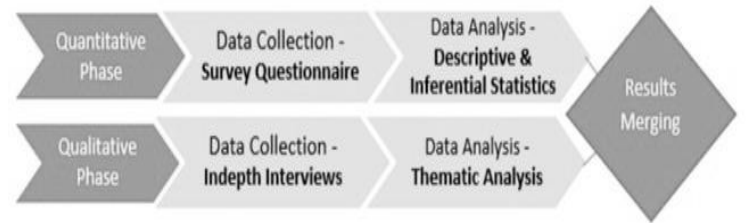

Fig. 1 Convergent parallel mixed methods

\section{B. Research Materials}

The researcher conducted a review of existing literature on agriculture forecasting while using databases, such as previous related research from online references, books, and journals. The information was extracted from the database was employed in the survey. Then lastly the data were collected through a survey questionnaire and interviews.

\section{Research Participants}

Participants in this study are 110 out of the actual list of 150 are the agricultural sector, which includes farmers, provincial and local agriculturists, organic farmers' association and entrepreneurs engage in buying and selling of the agricultural products in Negros Occidental province. The provincial and local agriculturist is responsible for implementing government programs, policies, and funding to improve the livelihood of the local farmers.

Through a simple random sampling, participants were identified from the provincial agriculturist department's local counterpart through the office of the city agriculturist that has the checklist of organic farmer associations and individuals available in the area.

\section{Research Procedures}

The survey questionnaire included closed-ended questions that were administered online and face-to-face. The former consisted of a web link to the online forms which is the same content used, which was emailed to randomly selected farmers, provincial and local agriculturists, and traders from the list given by the office of the city agriculturist, while the latter comprised printed hand-delivered copies. The survey questionnaire requested information regarding the respondents' demographic profile, the basic condition of agricultural product trading, attitude towards adapting technology and the factors in using technology to improve the quality of service of the agricultural production.

Semi-structured in-depth interviews were also conducted to uncover rich data in terms of opinions and experiences of participants on the subject. As the most common method for collecting qualitative data [15], it consists of guided openended questions to capture participants' verbal and nonverbal responses and to keep the focus. The quantitative data were analyzed using descriptive statistics, such as frequency and percentages via the Statistical Package for the Social Sciences (SPSS).

The 5-point Likert scale used in survey questionnaires as shown in Table 1 for the factors considered in the system development of agricultural forecasting. During the administered face-to-face data gathering, the researcher can explain the instruction and content of the survey using local dialect to accommodate those who were not properly educated and senior citizens who contributed to the development of the system. The survey questionnaire is also translated into the local dialect so that the respondent shall be able to honestly provide accurate and reliable data shall be gathered.

Table I. 5 points Likert scale to be considered in agricultural forecasting development.

\begin{tabular}{cccc}
\hline $\begin{array}{c}\text { Point } \\
\text { Score }\end{array}$ & $\begin{array}{c}\text { Range } \\
\text { Interval }\end{array}$ & $\begin{array}{c}\text { Descriptive } \\
\text { Rating }\end{array}$ & Description \\
\hline 1 & $4.20-5.00$ & Strongly Agree & $\begin{array}{c}\text { If the respondents } \\
\text { completely agree }\end{array}$ \\
\hline 2 & $3.40-4.19$ & Agree & $\begin{array}{c}\text { If the respondents } \\
\text { somewhat agree }\end{array}$ \\
\hline 3 & $2.60-3.39$ & $\begin{array}{c}\text { Neither Agree } \\
\text { nor Disagree }\end{array}$ & $\begin{array}{c}\text { If the respondents } \\
\text { neither agree nor } \\
\text { disagree }\end{array}$ \\
\hline 4 & $1.80-2.59$ & Disagree & $\begin{array}{c}\text { If the respondents } \\
\text { somewhat disagree }\end{array}$ \\
\hline 5 & $1.00-1.79$ & $\begin{array}{c}\text { Strongly } \\
\text { Disagree }\end{array}$ & $\begin{array}{c}\text { If the respondents } \\
\text { completely } \\
\text { disagree }\end{array}$ \\
\hline & & &
\end{tabular}

\section{RESULT AND DISCUSSION}

\section{A. Response Rate}

The sample size of the quantitative phase of this study was 110; however, 8 questionnaires were emailed with 102 being administered face-to-face to farmers, traders and the local agricultural sector. The distribution of respondents was identified as shown in Table 2, which represents a 100 percent response rate. 
Table 2. Distribution of Respondents

\begin{tabular}{ccc}
\hline \multicolumn{3}{c}{ Respondents' Distribution } \\
\hline & Frequency & Percentage \\
\hline Agriculturist & 4 & 3.6 \\
Farmers & 67 & 60.9 \\
Trader/Buyer & 39 & 35.5 \\
\hline
\end{tabular}

\section{B. Respondents and Organizations' Characteristics}

The respondents have equally distributed in which 57 percent of the male and 43 percent of the female participated. In which the characteristics of the respondents shown in Table 3 signified that it is essential and the demographic highlighted that a range of respondents' age was represented, which gave a good cross-section of opinions.

Also, the data indicated that the participants possessed educational qualifications and experience that are required to provide necessary information for the study. The majority of them worked in private companies and earned 40,000 pesos or more for agricultural production.

The respondents frequently use a mobile phone, followed by a tablet and laptop shown in Table 4 and Table 5 . Thus, on the technology that they owned, they mostly engage in a mobile phone for communicating and learning new things through the Internet.

Table 3. Respondents' Characteristics.

\begin{tabular}{|c|c|c|}
\hline \multicolumn{3}{|c|}{ Age of Respondents } \\
\hline $18-29$ years & 30 & 27.3 \\
\hline $30-39$ years & 29 & 26.4 \\
\hline $40-49$ years & 21 & 19.1 \\
\hline $50-59$ years & 21 & 19.1 \\
\hline Over 60 years & 9 & 8.2 \\
\hline \multicolumn{3}{|c|}{ Level of Education } \\
\hline Elementary Graduate & 2 & 1.8 \\
\hline High School Graduate & 20 & 18.2 \\
\hline $\begin{array}{l}\text { Attended College but did not } \\
\text { finish }\end{array}$ & 19 & 17.3 \\
\hline $\begin{array}{l}\text { Vocational/Technical Degree or } \\
\text { Certificate }\end{array}$ & 9 & 8.2 \\
\hline Associate Degree & 12 & 10.9 \\
\hline Bachelor's Degree & 42 & 38.2 \\
\hline Master's or Doctoral Degree & 6 & 5.5 \\
\hline \multicolumn{3}{|c|}{ Respondents' Occupation } \\
\hline Government Service & 15 & 13.6 \\
\hline Private Service & 45 & 40.9 \\
\hline Self Employed & 25 & 22.7 \\
\hline Aggricultural Farmer & 13 & 11.8 \\
\hline Other & 12 & 10.9 \\
\hline \multicolumn{3}{|c|}{ Income from Agricultural Production } \\
\hline Less than 10,000 pesos & 1 & 0.9 \\
\hline 10,001 to 20,000 pesos & 9 & 8.2 \\
\hline 20,001 to 30,000 pesos & 21 & 19.1 \\
\hline 30,001 to 40,000 pesos & 41 & 37.3 \\
\hline Above 40,001 pesos & 38 & 34.5 \\
\hline
\end{tabular}

Table 4. Frequent use technology

\begin{tabular}{lcccc}
\hline \multicolumn{4}{c}{ Frequency } \\
\hline & \multicolumn{3}{c}{ Responses } & Percent of \\
\cline { 3 - 4 } & Desktop & 2 & $1.2 \%$ & $1.8 \%$ \\
& Laptop & 16 & $9.8 \%$ & $14.5 \%$ \\
\multirow{4}{*}{ Frequent use } & Tablet & 37 & $22.6 \%$ & $33.6 \%$ \\
& Mobile phone & 104 & $63.4 \%$ & $94.5 \%$ \\
& No technology & 5 & $3.0 \%$ & $4.5 \%$ \\
\hline Total & 164 & $100.0 \%$ & $149.1 \%$ \\
\hline
\end{tabular}

a. Dichotomy groum tabulatad at vahe 1 .

Table 5. Most use technology

\begin{tabular}{lcccc}
\hline \multicolumn{4}{c}{ Frequency } \\
\hline & Laptop & 1 & $1.0 \%$ & $1.0 \%$ \\
\cline { 2 - 3 } & $\mathrm{N}$ & Percent & $\begin{array}{c}\text { Cercent of } \\
\text { Cases }\end{array}$ \\
\hline \multirow{3}{*}{ Most use } & Tablet & 6 & $5.7 \%$ & $5.8 \%$ \\
& Mobile phone & 98 & $93.3 \%$ & $94.2 \%$ \\
\hline Total & 105 & $100.0 \%$ & $101.0 \%$ \\
\hline
\end{tabular}

a. Dichotony group tabulated at vahe 1 .

\section{Basic Conditions of Agricultural Product Trading}

The results of the quantitative data revealed that the condition of farmers and buyers in the market are not fully addressed. This affected the trading post in terms of the production of farm products. The average mean is at 2.63 which the respondents' neither agreed nor disagreed with some conditions imposed on farmers during trading of their crops. This results in a lack of coordination between the farmers/buyers and the management of the trading post wherein the agricultural farm products suffer most.

Table 6. Basic Condition of agriculture buying of products

\begin{tabular}{|c|c|c|}
\hline Evaluation Criteria & Mean & Descriptive Rating \\
\hline $\begin{array}{l}\text { 1. The farmeris directly } \\
\text { contacted by the buyer to buy } \\
\text { the product. (Ang } \\
\text { mangunguma ginakadtuan } \\
\text { diretso sangmanugbakal sang } \\
\text { iya produkto.) }\end{array}$ & 2.55 & Neither Agree nor Disagree \\
\hline $\begin{array}{l}\text { 2. The farmer has a loyal } \\
\text { buyer where he/she brought } \\
\text { the product. (Ang } \\
\text { mangunguma may ara na sang } \\
\text { suki nga pagadalan sangiya } \\
\text { produkto.) }\end{array}$ & 2.57 & Neither Agree nor Disagree \\
\hline $\begin{array}{l}\text { 3. The farmer is the one that } \\
\text { brings the product to the } \\
\text { trading post and sell. (Ang } \\
\text { mangunguma na lang ang } \\
\text { nagadala sa bagsakan sangiya } \\
\text { produkto kagmagbaligya.) }\end{array}$ & 2.65 & Neither Agree nor Disagree \\
\hline $\begin{array}{l}\text { 4. The farmer has his/her own } \\
\text { list/ idea where to sell the } \\
\text { product. (Ang mangunguma } \\
\text { may ara na sanglistahan/ideya } \\
\text { kon diin nya ibaligya iya } \\
\text { produkto.) }\end{array}$ & 2.61 & Neither Agree nor Disagree \\
\hline $\begin{array}{l}\text { 5. The farmer is informed } \\
\text { days before buying the } \\
\text { product. (Ang mangunguma } \\
\text { ginapabalo sangmanugbakal } \\
\text { pila ka a dlawbag-o nya baklon } \\
\text { ang produkto.) }\end{array}$ & 2.72 & Neither Agree nor Disagree \\
\hline
\end{tabular}



APPLICATION FOR FARMERS

\begin{tabular}{|c|c|c|}
\hline $\begin{array}{l}\text { 6. The trading post is } \\
\text { monitoring the product being } \\
\text { sold. (Ang bagsakanmay } \\
\text { monitoring sangmabakalnga } \\
\text { produkto nga ginadala sa ila.) }\end{array}$ & 2.81 & Neither Agree nor Disagree \\
\hline $\begin{array}{l}\text { 7. The trading post informed } \\
\text { the excess and inadequate } \\
\text { product to the farmer. (Ang } \\
\text { bagsakan ginapabalo ang } \\
\text { mangunguma sa sobra kag } \\
\text { kulang nga produkto.) }\end{array}$ & 2.60 & Neither Agree nor Disagree \\
\hline
\end{tabular}

post has a policy regulated on all agricultural product brought in the trading post. (Ang 2.59 Disagree mga produkto nga ginadala sa bagsakan.)

9. The trader's co-ordinates on the management of the trading post before buying the agricultural products. (Ang manugbakal ga koordinar sa tagapamuno sang bagsakan bag-o magbakal sang produkto.)

10. The farmers coordinate on the management of the trading post on the agricultural productshe/she sell. (Ang mangunguma naga 2.57 Disagree koordinar sa tagapamuno sang bagsakan sa produkto nga iya ginabaligya.)

\begin{tabular}{|c|c|c|}
\hline $\begin{array}{l}\text { 11. The farmers informed the } \\
\text { management of the trading } \\
\text { post before selling the } \\
\text { product. (Ang mangumnguma } \\
\text { gapabalo sa tagapamuno sang } \\
\text { bagsakan bag-o magbaligya } \\
\text { sangiya produkto.) }\end{array}$ & 2.55 & Disagree \\
\hline $\begin{array}{l}\text { 12. There is a contract or } \\
\text { agreement between the trader } \\
\text { and farmer even during } \\
\text { planting of the agricultural } \\
\text { product. (Ginakontrata na sang } \\
\text { manugbakal ang produkto sang } \\
\text { mangunguma samtang } \\
\text { ginatanompalang.) }\end{array}$ & 2.76 & Neither Agree nor Disagree \\
\hline $\begin{array}{l}\text { 13. The monitoring of the } \\
\text { price of the agricultural } \\
\text { product is being implemented } \\
\text { based on the mandate of the } \\
\text { local government. (Ang } \\
\text { monitoring sangpresyuhanay } \\
\text { sangprodukto ginamando } \\
\text { sunod sa gina implimintar sang } \\
\text { pamumuanlokal.) }\end{array}$ & 2.62 & Neither Agree nor Disagree \\
\hline $\begin{array}{l}\text { 14. The implemented price of } \\
\text { the product is in favor of the } \\
\text { farmer. (Ang presyuhanay } \\
\text { sangprodukto gina implimintar } \\
\text { nga pabor sa mangunguma) }\end{array}$ & 2.71 & Neither Agree nor Disagree \\
\hline $\begin{array}{l}\text { 15. The price of the } \\
\text { agricultural product is based } \\
\text { on the current market value. } \\
\text { (Ang presyuhanay sang } \\
\text { produktonaga basiman sa } \\
\text { subongnga mga presyosa } \\
\text { merkado.) }\end{array}$ & 2.65 & Neither Agree nor Disagree \\
\hline Average Mean Score & 2.63 & Neither Agree nor Disagree \\
\hline
\end{tabular}

\section{Attitude Towards Adapting Technology}

The positive result of the respondents in adapting and engaging in technology is helpful to develop an application that shall suit the needs and requirements of the farmers and agricultural sectors. Table 7 represents the willingness of the respondents to learn every aspect of the forecasting system to solve the common problems as to how it shall benefit the farmers to sell their products. They are confident and enjoy using technology for personal and recreational matters.

Table 7. Attitudes in adapting the technology

\begin{tabular}{|c|c|c|}
\hline Evaluation Criteria & Mean & Descriptive Rating \\
\hline $\begin{array}{l}\text { 1. I am confident using } \\
\text { technology for personal } \\
\text { or recreational matters }\end{array}$ & 4.03 & Agree \\
\hline $\begin{array}{l}\text {. I enjoy using } \\
\text { technology for personal/ } \\
\text { recreationalmatters. }\end{array}$ & 4.33 & Strongly Agree \\
\hline $\begin{array}{l}\text { 3. I have a positive } \\
\text { attitude towards } \\
\text { technology for } \\
\text { recreationalmatters. }\end{array}$ & 4.09 & Agree \\
\hline $\begin{array}{l}\text { 4. I enjoy using } \\
\text { technology to leam. }\end{array}$ & 4.14 & Agree \\
\hline $\begin{array}{l}\text { 5. I am confident using } \\
\text { technology to leam. }\end{array}$ & 4.22 & Strongly Agree \\
\hline $\begin{array}{l}\text { 6. I have a positive } \\
\text { attitude towards } \\
\text { technology for leaming. }\end{array}$ & 4.14 & Agree \\
\hline $\begin{array}{l}\text { 7. I enjoy using } \\
\text { technology to explore } \\
\text { topics of interest. }\end{array}$ & 4.16 & Agree \\
\hline $\begin{array}{l}\text { 8. I have a positive } \\
\text { attitude that, using the } \\
\text { Intemet and technology } \\
\text { keep me updated on the } \\
\text { topics of interest }\end{array}$ & 4.13 & Agree \\
\hline $\begin{array}{l}\text { 9. I enjoy leaming many } \\
\text { things by interacting with } \\
\text { other Intemet user. }\end{array}$ & 4.06 & Agree \\
\hline $\begin{array}{l}\text { 10. I like to share my } \\
\text { interest and reflection } \\
\text { online. }\end{array}$ & 3.98 & Agree \\
\hline Average Mean Score & 4.13 & Agree \\
\hline
\end{tabular}

E. Factors Using Technology in Improving the Quality of Agricultural Production

The result of the factors that are being considered in the development of the agricultural forecasting system shown in Table 8, is widely accepted by the respondents. The monitoring of the available and needed agricultural products and price are the most essential for the farmers which are 4.41 and 4.35 respectively. This information is the basis for the architectural design on the development of the agricultural forecasting system that shall be then implemented to Negros Occidental provincial supported farmers in trading of agricultural products.

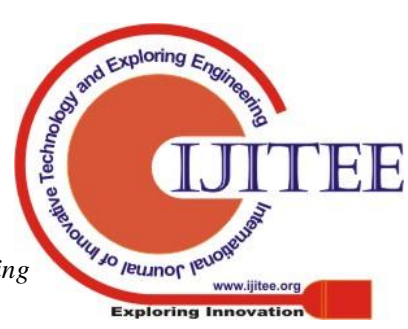


Table 8. Factors that shall improve agricultural production.

\begin{tabular}{lcc}
\hline Evaluation Criteria & Mean & Descriptive Rating \\
\hline $\begin{array}{l}\text { 1. The farmers mustbe } \\
\text { updated on the product }\end{array}$ & 3.75 & Agree \\
available in the trading \\
post or market.
\end{tabular}

\begin{tabular}{|c|c|c|}
\hline $\begin{array}{l}\text { 2. The farmers and buyer } \\
\text { should have open } \\
\text { communication to } \\
\text { address the problem in } \\
\text { agricultural production. }\end{array}$ & 3.85 & Agree \\
\hline $\begin{array}{l}\text { 3. The farmers should be } \\
\text { informed of the demand } \\
\text { and supply in the } \\
\text { different participating } \\
\text { trading post. }\end{array}$ & 3.89 & Agree \\
\hline $\begin{array}{l}\text { 4. The farmer has an } \\
\text { option where to sell } \\
\text { agricultural products. }\end{array}$ & 3.85 & Agree \\
\hline $\begin{array}{l}\text { 5. The farmers can inform } \\
\text { the trading post of the } \\
\text { agricultural products to } \\
\text { sell. }\end{array}$ & 4.32 & Strongly Agree \\
\hline $\begin{array}{l}\text { 6. The farmer and buyer } \\
\text { can monitor the demand } \\
\text { and supply of the } \\
\text { agricultural products } \\
\text { imposedby the trading } \\
\text { post. }\end{array}$ & 4.41 & Strongly Agree \\
\hline
\end{tabular}

7. The farmers can locate the participating trading post of the available 4.26 Strongly Agree agricultural products. 8. The trading post should have monitoring of the price that is good to notify 4.35 Strongly Agree the buyer and farmers.

\begin{tabular}{|c|c|c|}
\hline $\begin{array}{l}\text { 9. The trading post can } \\
\text { regulate the current } \\
\text { market value of } \\
\text { agricultural products. }\end{array}$ & 4.25 & Strongly Agree \\
\hline
\end{tabular}

10 The trading post has the ability to inform the buyer and farmer of the $4.32 \quad$ Strongly Agree demand and supply of the agricultural product

Average Mean Score $\quad 4.17 \quad$ Agree

F. The proposed Architectural Framework for the Mobile Application

The proposed mobile application will address the agricultural sector, especially the farm owners by means of improving the service to combat the food waste being shown in Fig. 2. It includes the tailored features identified through the result in the survey that is conducted. Thus, the proposed system has a price monitoring which is important for the

farmers and traders in decision making as to sell and buy the crops. Mapping the trading post through GPS locator will easily provide comfort to farmers where to market their crops. The monitoring of the supply and demand of the crop value will keep the farmers up-to-date on the crop they are planning to plant and harvest. Notification is included to inform and update the users on some trading management advisory.

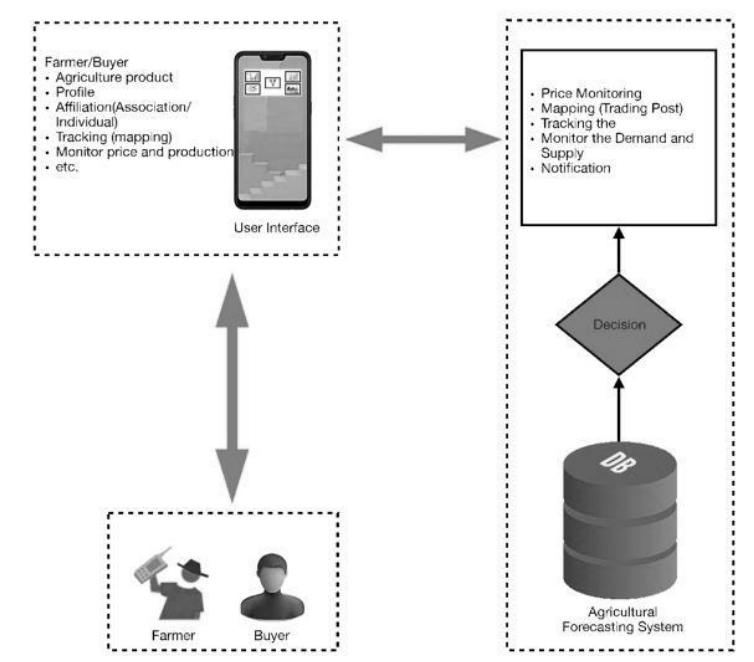

Fig. 2 Proposed Design for Mobile Application

\section{CONCLUSION}

The given result is positively provides the researchers an in-depth idea that the project can support the program of the government, especially in the agricultural sector to come up with a plan in developing a system that assists the farmers to overcome the problem on where to sell their products and also to support the government in making sure that the production shall not be wasted due to lack of buyer since the farmers, buyer and agricultural sector are open to support the idea.

The researchers proposes the following recommendation to improve the situation of farm to market activities between agricultural sectors, farmers and buyer: 1) Implementation of the architectural design to determine the factors in the system development and 2) The development of the agricultural forecasting system which shall provide a solution to agricultural farmer especially in selling their product.

\section{REFERENCES}

1. K. Ash, "Further agricultural reforms in the Philippines would help reduce poverty and improve food security," [online] Available https://www.oecd.org/agriculture/further-agriculturalreforms-in-the-philippines-would-help-reduce-povertyand-improve-food-security.htm [Accessed 18 Feb. 2019]

2. Fee.org. (2019). The Farm Problem and Government Farm Programs, E.C. Pasour. [online] Available at: https://fee.org/articles/the-farm-problem-andgovernment-farm-programs/ [Accessed 21 Feb. 2019].

3. Trobe, Helen La. "Farmers' markets: consuming local 
rural produce." International journal of consumer studies 25, no. 3 (2001): 181-192.

4. Zhang, Wensheng, Hongfu Chen, and Mingsheng Wang. "A forecast model of agricultural and livestock products price." In International Conference on Computer and Computing Technologies in Agriculture, pp. 40-48. Springer, Berlin, Heidelberg, 2009.

5. Guzman, S. S. (2018, June 17). Agriculture is dying in the Philippines. Retrieved from https://www.philstar.com/opinion/2018/06/18/1825542/a griculture-dying-philippines [Accessed 21 Feb. 2019].

6. [6] Gelb, Ehud M. "Adoption of IT by farmersDoes reality reflect the potential benefit." In Proceedings Second European Conference EFITA, pp. 433-441. 1999.

7. Thysen, Iver. "Agriculture in the information society." Journal of agricultural engineering research 76 , no. 3 (2000): 297-303.

8. Ascough II, James C., Dana L. Hoag, W. Marshall Frasier, and Gregory S. McMaster. "Computer use in agriculture: an analysis of Great Plains producers." Computers and electronics in agriculture 23, no. 3 (1999): 189-204.

9. Allen, P. Geoffrey. "Economic forecasting in agriculture." International Journal of Forecasting 10, no. 1 (1994): 81-135.

10. Wyche, Susan, and Charles Steinfield. "Why don't farmers use cell phones to access market prices? Technology affordances and barriers to market information services adoption in rural Kenya." Information Technology for Development 22, no. 2 (2016): 320-333.

11. Warren, Martyn. "Farmers online: drivers and impediments in adoption of Internet in UK agricultural businesses." Journal of Small Business and Enterprise Development 11, no. 3 (2004): 371-381.

12. Esa. (n.d.). Agricultural forecasting. Retrieved from https://www.esa.int/Our_Activities/Observing_the_Earth /Benefiting_Our_Economy/Agricultural_forecasting [Accessed 5 Jun. 2019].

13. McCue, C. (2014). Data mining and predictive analysis: Intelligence gathering and crime analysis. ButterworthHeinemann.

14. Virginia Braun \& Victoria Clarke, Using thematic analysis in psychology, in Qualitative Research in Psychology, Volume 3(2), 2006.

15. Bhattacherjee, A. Social Science Research: Principles, Methods, and Practices; Global Text Project: Athens, Georgia, 2012. 